\title{
PENGEMBANGAN MEDIA 3D UNTUK MENGKONSTRUKSI KETERAMPILAN MEMANIPULASI SISWA VOKASI
}

\author{
Erry Sutiono, I Nyoman Sudana Degeng, Henry Praherdiono \\ Jurusan Teknologi Pendidikan, Fakultas Ilmu Pendidikan, Universitas Negeri Malang \\ Jalan Semarang 5 Malang 65145 0341-574700 \\ Email: eric.wewek@gmail.com
}

Article History

Received: 20 September 2020, Accepted: 31 Desember 2020, Published: 10 Agustus 2021

\begin{abstract}
Abstrak
Produk berupa obyek seni rupa 3D untuk mengkonstruksi keterampilan memanipulasi siswa SMKN 1 Udanawu kelas X. Obyek media 3D berbentuk video animasi digital yang ditampilkan pada LCD atau perangkat lainnya. Kelebihan Obyek media 3D digital yaitu media obyek 3D dapat dilihat dari segala arah. Sehingga siswa dapat mengamati obyek media 3D secara keseluruhan. media 3D menggunakan model pengembangan oleh William W. Lee dan Diana L. Owens (2004). Penerapan media 3D seni rupa hanya sampai pada tahap uji validasi media dan validasi materi. Dari hasil ahli validasi dapat disimpulkan bahwa media 3D valid dan layak digunakan dalam pembelajara. Obyek media 3D dapat mengkonstruksi keterampilan memanipulasi siswa dalam berkarya seni dan meningkatkan minat serta motivasi belajar siswa. Obyek media 3D sebagai alat bantu guru dalam menyelesaikan masalah pembelajaran.
\end{abstract}

Keyword: Media; 3D; Mengkonstruksi Keterampilan; Memanipulasi

\begin{abstract}
This study resulted in a three-dimensional art object to construct the skills of manipulating SMKN 1 Udanawu class X. The three-dimensional media object form a digital animation video displayed on the LCD or other device. The excess digital three-dimensional media object is that three-dimensional object media can be viewed from all directions. So students can observe the overall three-dimensional media object. Three-dimensional media research uses models of development by William W. Lee and Diana L. Owens (2004). The implementation of three-dimensional media of fine arts only reached the test stage of media validation and material validation. From the results of the validation experts can be concluded that the three-dimensional medium is valid and feasible to use. Three-dimensional media objects can construct students ' manipulating skills in art and increase the interest and motivation of student learning. Three-dimensional media objects can help teachers solve problem-solving problems..
\end{abstract}

Keyword: Media; 3D; Constructing Skills; Manipulate 


\section{PENDAHULUAN}

Perkembangan teknologi dalam pendidikan semakin berkembang. Kemajuan teknologi semakain canggih memberikan kemudahan pada segala aspek kehidupan. Pembelajaran pemanfaatan teknologi sangat dibutuhkan untuk menunjang pembelajaran. Teknologi pembelajaran merupakan kemajuan pengembangan teknologi (Muhammad Yaumi, M. Hum, M.A, 2018). Seels dan Richey (1994:43) mengungkapkan bahwa asal kawasan pengembangan produksi media menyebabkan perubahan teknologi pembelajaran.

Media merupakan perantara untuk mentransfer ilmu kepada siswa. Pernyataan (Sadiman, Arief S. dkk, 2010) mendifinisikan media adalah alat menyampaikan pesan dari komunikator ke komunikan (pemberi pesan dan penerima pesan) dalam pembelajaran untuk merangsang perasaan, perhatian, pikiran, dan minat siswa. Donald P.Ely dan Vemon Gerlach (1997:2) menyatakan media memiliki dua pengertian, media dalam arti sempit dan arti luas. Media dalam arti sempit merupakan wujud foto, grafik, elektronik dan alat mekanik digunakan memproses serta menyampaikan informasi. Sedangkan media secara umu merupakan kegiatan menciptakan suatu kondisi dan memungkinkan siswa memperoleh keterampilan dan pengetahuan.

Dalam pendidikan, menggunakan media untuk sarana pembelajaran di dalam kelas. Daryanto (2014:4) mengatakan media pembelajaran sebagai alat untuk menyalurkan pesan dari sumber untuk mencipatakan proses pembelajaran yang efektif (Munadi, 2013:7). Media digunakan dalam proses pembelajaran oleh pendidik sebagai penyampai pesan kepada anak didik. Media tersebut mampu mengubah anak didik mendapatkan informasi baru serta pola belajar. Pemanfaatan teknologi mengatasi permasalahan dalam pembelajaran. Henderson et al, (2017) mengatakan teknologi berbentuk digital mampu meningkatkan pembelajaran siswa. Teknologi berbentuk digital menarik minat belajar anak didik. Penggunaan software dapat membentuk obyek tiruan 3D sehinggap dapat menyerupai bentuk aslinya. Menurut Edgar Dale menyatakan "kejadian-kejadian, atau benda sebenarnya sulit diperoleh, mungkin juga berukuran besar atau jangkaunnya jauh dapat membentuk obyek tiruan dengan rupa sebenarnya, hanya ukurannya tidak sama". Pembuatan obyek tiruan merupakan pemanfaatan media yang efektif.

Menurut Plowman (2016) mendefinisikan teknologi berbentuk digital ditinjau sebagai perangkat digital seperti (komputer atau smartphone) dan aplikasi atau situs web dapat dijalankan dan dibaca. Maka pemanfaatan teknologi berbentuk digital dijadikan media pembelajaran. Obyek 3D dapat divisualisasikan pada layar monitor atau LCD proyektor yang dijalankan oleh komputer. Pitoyo Widhi Atmoko (2015) mengatakan digitalisasi merupakan proses perubahan media informasi analog ke media digital. Keuntungan digitilasi meliputi, mewakili sumber asli, lebih hemat dan mudah dalam penyampaian, dan lebih interaktif.

Pada kelas 10 mata pelajaran seni budaya terdapat materi seni rupa 3D. Tujuan materi seni rupa 3D adalalah mengetahui contoh seni rupa 3D, komponen, fungsi, dan cara pembuatan. Pembuatan obyek media 3D mengambil contoh benda-benda di lingkungan sekitar. Adanya media 3D obyek lebih detail dapat diamati dari berbagai arah. Membantu anak didik membangun keterampilan memanipulasi obyek media 3D. Keterampilan siswa menggunakan tangan dapat membuat, mengolah, dan mengatur bentuk sesuai keterampilan siswa.

Berdasarkan observasi diketahui sekolah menyediakan beberapa media pembelajaran, diantaranya Proyektor dan komputer. Untuk proses pembelajaran sekolah juga memiliki laboratorium komputer di setiap program keahlian. Pemanfaatan media belum digunakan secara maksimal. Komputer hanya digunakan saat praktik kejuruan. Dalam pelajaran lain belum memanfaatkan komputer.

Setelah melakukan wawancara kepada guru Seni Budaya, dalam pembelajaran teori dan contoh 3D cenderung melihat gambar dari buku. Siswa mengamati contoh benda 3D dalam buku pelajaran. 
Beliau merasa bila ada media sangat membantu guru dan siswa. Pembelajaran media 3D menyesuaikan dengan pembelajaran.

Mengembangkan pembelajaran berbasis komputer untuk materi seni rupa 3D berbentuk digital dapat diamati dari berbagai arah. Anak didik mengamati langsung detail obyek 3D dari bahan, komponen, fungsi, dan bentuk. Benda tiruan di dalam kelas mempermudah anak didik mengkonstruksi keterampilan memanipulasi dan membuat kembali dengan ukuran berbeda. Keterampilan memanipulasi siswa adalah pembuatan kembali obyek dengan tangan siswa. Herbert Read (1959), menyebutkan seni merupakan usaha seseorang untuk membuat bentuk yang indah. Karya seni 3D dibagi menjadi karya seni rupa terapan berdasarkan fungsi pakai dan karya seni rupa murni berdasarkan ekspresi saja. Perbedaan seni dibedakan berdasarkan tujuan pembuatannya. Benda tersebut semakin indah dilihat dan nyaman digunakan.

Hasil sebelumnya yang berjudul "Rancang Bangun Animasi 3D Sebagai Media Pembelajaran Pada Mata Pelajaran Menginstalasi PC" (Yuningsih, 2018), dalam pengembangan tersebut menghasilkan produk animasi 3D untuk menginstalasi PC pada Program TKJ. Dalam pengembangan yang berjudul "Pengembangan Media 3D Vacuum Circuit Breaker Memanfaatkan Piramida Hologram" (Kurniawan, 2014) hasil media 3D dapat menarik minat dan motivasi siswa pembelajaran vacuum circuit breaker.

\section{Obyek Media 3D}

Media dalam bentuk dan ciri fisik mempunyai ukuran panjang, lebar,tinggi, dan dapat diamati dari berbagai arah. Obyek 3D menjadi alat peraga dan disebut media visual. Obyek 3D dibuat menggunakan komputer atau perangkat lainnya dengan menampilkan benda tiruan dan dapat diamati dari berbagai arah. Obyek 3D termasuk pembelajaran benda tiruan. Benda tiruan membuat kembali bentuk nyata dengan ukuran berbeda. Model menurut Sihkabuden (2011:80) adalah benda tiruan menyerupai aslinya tetapi berbeda dengan lainnya. Pemanfaatan model mengatasi masalah belajar di dalam kelas. Seperti obyek berukuran besar sulit untuk mengamati keseluruhan.

Keuntungan pemanfaatan model untuk media pembelajaran menurut Sihkabuden (2011:8) (a) Model memiliki bentuk 3D, walaupun bukan benda sebenarnya, digunakan pengganti benda sebenarnya. (b) Perubahan ukuran, perubahan ukuran model mudah dipelajari, model dapat diperkecil dan diperbesar. (c) Bagian yang penting dihilangkan, misalnya mengambil bagian penting model kemudian disederhanakan. (d) Menunjukkan struktur bagian dari benda tiruan, melalui model irisan dapat melihat struktur bagian benda yang tidak bisa dilihat dalam keadaan aslinya. (e) Kekongkritan tak langsung, melewati model mendapatkan pengalaman kongkrit meskipun tidak melihat benda sebenarnya.

\section{Mengkonstruksi Keterampilan Memanipulasi Siswa}

Ranah psikomotorik (keterampilan) pencapainnya melalui keterampilan memanipulasi dengan otot dan fisik. Reaksi fisik dan keterampilan tangan merupakan penekanan yang diorientasikan dengan keterampilan yang dikaitkan dengan seni budaya. Keterampilan menunjukkan tingkat keahlian seseorang dalam mengerjakan sesuatu. Mardapi (2003:143), psikomotorik (keterampilan) dibagi menjadi 6 tahap, yaitu gerakan refleks, dasar, kemampuan perseptual, gerak fisik, terampil, komunikasi nondiskursif. Gerakan refleks merupakan respon atau gerak tanpa sadar. Gerakan dasar merupakan gerakan keterampilan kompleks. Kemampuan perseptual merupakan kombinasi kemampuan kognitif dan motorik. Kemampuan fisik merupakan kemampuan gerak terampil. Gerak terampilan merupakan gerakan dengan keterampilan belajar, seperti keterampilan olahraga. Komunikasi nondiskursif adalah keterampilan berkomunikasi menggunakan gerakan.

Pemanfaatan media 3D bertujuan mengkonstruksi keterampilan memanipulasi anak didik. Peserta didik menguasai keterampilan motorik diantaranya menulis, mengingat, dan menggunakan alat untuk 
menghasilkan kreasi, dan melakukan gerakan. Peserta didik dapat memanipulasi sebuah benda dengan keterampilan masing-masing siswa. Media 3D memiliki fungsi memberikan motivasi kepada peserta didik dengan adanya komponen multimedia untuk belajar.

\section{METODE}

Rancangan seluruh pengembangan dengan sistematis metode pengembangan. Pengembangan 3D dengan materi seni rupa mata pelajaran Seni Budaya kelas 10 SMKN 1 Udanawu. Pembuatan media 3D menggunakan program pengolag grafis dan editing video.

Pengembangan 3D menggunakan metode Lee \& Owens (2004:3). Alasan peneliti menggunakan metode pengembangan Lee \& Owens (2004:3) adalah metode pengembangan mempunyai tahapan rinci dan lengkap, mulai dari analisis dan penilaian, desain, pengembangan, implementasi, dan evaluasi yang dirasa sangat tepat untuk pengembangan produk media 3D. Model pengembangan ini bertujuan untuk mengembangkan media pembelajaran.

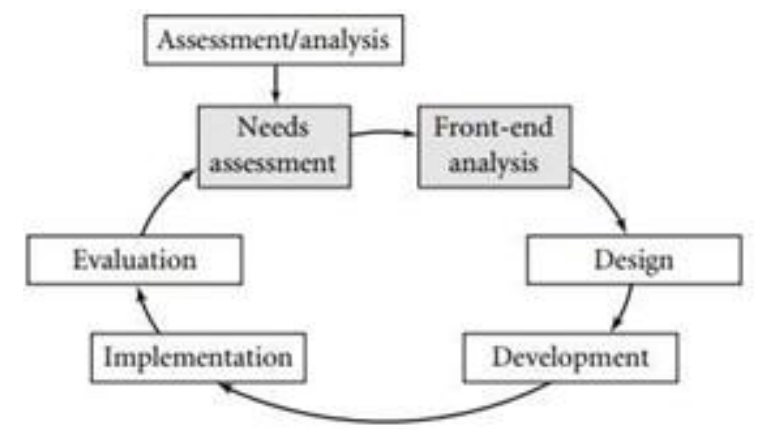

Gambar 1. Model Pengembangan Lee \& Owens (2004)

Prosedur pengembangan 3D sesuai dengan metode pengembangan Lee \& Owens adalah sebagai berikut : (1) Assessment/analisis terdiri dari dua bagian utama yaitu analisis kebutuhan dan analisis Front-End; (2) Desain; (3) Pengembangan; (4) Implementasi; (5) Evaluasi. Pada tahap ini hanya akan dilaksanakan sampai tahap Development/Pengembangan.

Kegiatan uji kelayakan dan uji coba produk dilaksanakan untuk mendapatkan data untuk meningkatkan keberhasilan media 3D. Kegiatan tersebut terdiri dari uji kelayakan ahli materi dan media. Angket Pengembangan media 3D untuk memperoleh data berupa kuantitatif dan data kualitatif. Data kualitatif berbentuk komentar, saran, dan pendapat tentang media 3D dari ahli media dan ahli materi. Data kuantitatif berupa penilaian berbentuk angka dari hasil penilaian angket media 3D.

Instrumen untuk menguji kelayakan media 3D berupa angket. Penilaian angket dari ahli media dan ahli materi menggunakan pengukuran rating scale dengan empat jawaban yaitu, SS (Sangat Setuju), S (Setuju), TS (Tidak Setuju) dan STS (Sangat Tidak Setuju). Pada angket kelayakan ahli media aspek yang dinilai seperti fungsi dan manfaat, aspek visual, audio, tipografi, bahasa, dan pemrograman. Aspek fungsi dan manfaat berupa memperjelas dan mempermudah penyampaian pesan, membangkitkan minat dan motivasi siswa, dan membangkitkan kreativitas siswa. Aspek visual media berisi kemenarikan warna, background, gambar, dan audio, kesesuaian ukuran gambar, serta kejelasan gambar. Aspek audio seperti ritme suara, kejelasan suara, dan kesesuaian suara dengan materi. Aspek berikutnya merupakan tipografi yang berisi tentang pemilihan jenis teks dan ketepatan ukuran teks. Aspek paling penting yaitu bahasa tentang ketepatan bahasa, efektivitas kata, istilah, dan kalimat, serta kemudahan memahami alur materi melalui penggunaan bahasa. Aspek terakhir yaitu pemrograman media tentang kemutakhiran media pembelajaran.

Angket kelayakan ahli materi juga memiliki berbagai aspek yang dinilai seperti keakuratan materi, koherensi dan keruntutan materi, serta kemutakhiran materi. Aspek keakuratan materi indikator yang dinilai seperti keakuratan konsep dan definisi, keakuratan data dan fakta, keakuratan 
contoh dan kasus, keakuratan ilustrasi, keakuratan istilah-istilah, keakuratan gambar, dan keakuratan petunjuk penggunaan. Aspek koherensi dan keruntutan materi berisi ketertautan antar kegiatan belajar/sub kegiatan belajar/alinea, keutuhan makna dalam kegiatan belajar/sub kegiatan belajar/alinea, keruntutan materi, dan kesesuaian penggunaan waktu mengerjakan soal. Aspek terakhir untuk ahli materi adalah aspek kemuktahiran kesesuaian dengan materi, ilustrasi, menggunakan contoh kasus, dan kesesuaian hasil atau penilaian.

Penilaian ahli media dan materi dianalisis dengan teknik kualitatif dan kuantitatif. Data kualitatif dianalisis menggunakan isi, saran, tanggapan, dan kritik dari validator. Sedangkan data kuantitatif dianalisis menggunakan teknik analisis persentase. Teknik persentase merupakan cara mengubah data kuantitatif menjadi bentuk persentase. Kemudian dijelaskan menggunakan kalimat kualitatif. Teknik analisis digunakan menjelaskan hasil pengembangan media 3D dan mengukur keberhasilan produk pengembangan.

\section{HASIL}

Data pengembangan media dilakukan dalam dua tahap. Tahap pertama penilaian ahli media oleh dosen Teknologi Pendidikan UM, tahap kedua penilaian pendidik pelajaran Seni Budaya di SMKN 1 Udanawu. Data hasil pengembangan media memperoleh hasil berupa data kualitatif dan kuantitatif. Data kuantitatif berupa angka dan kualitatif berupa saran atau komentar yang diberikan ahli media dan ahli materi.

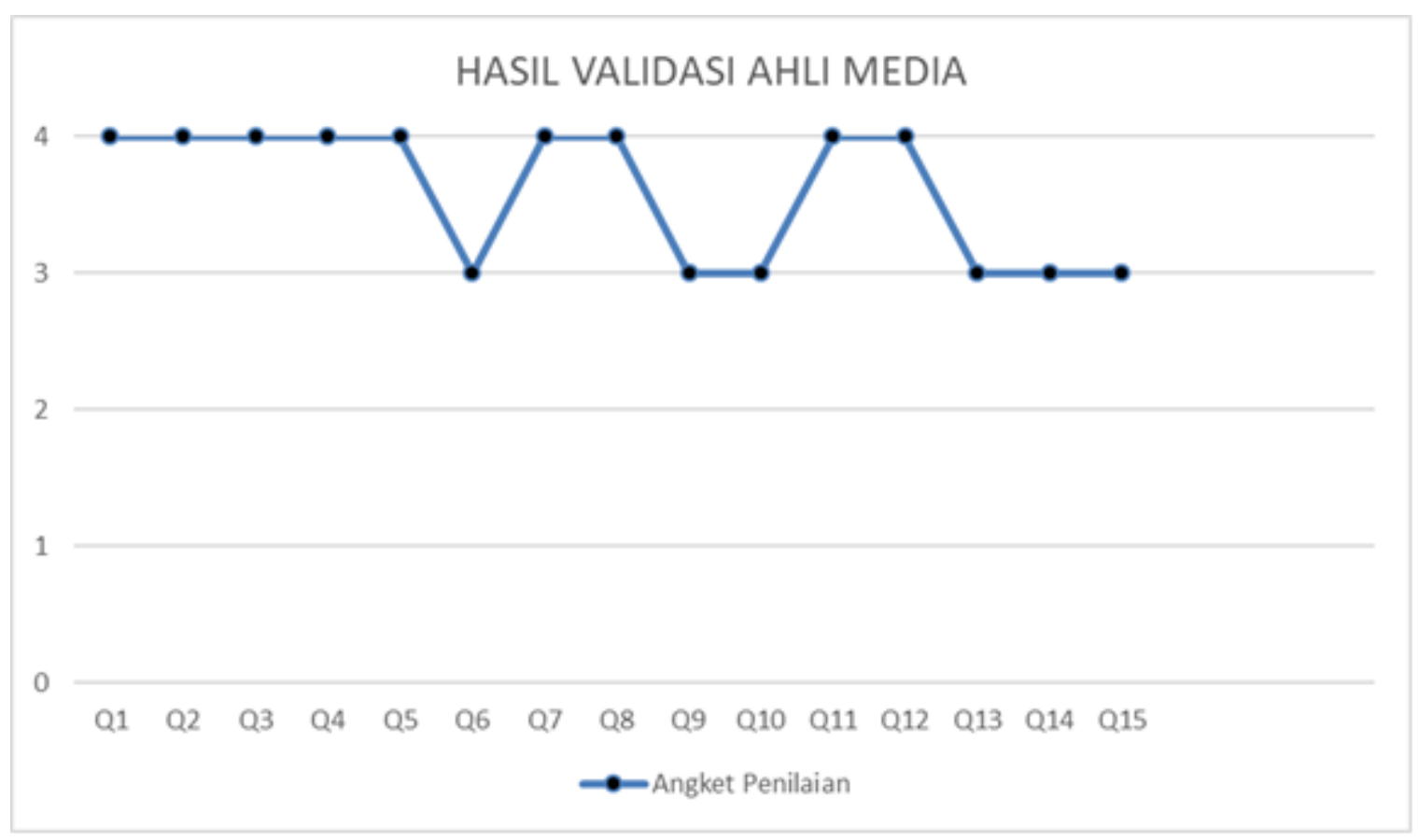

\section{Grafik 1 Respon Ahli Media}

Berdasarkan penyajian grafik 1 sebanyak 9 item menjawab dengan nilai 4. Aspek yang tersaji dalam angket dengan perolehan nilai 4 meliputi aspek memperjelas dan mempermudah penyampian pesan, membangkitkan minat dan motivasi belajar siswa, membangkitkan imajinasi siswa, membangkitkan kreativitas siswa, pemanfaatan penggunaan media obyek 3D, kesesuaian ukuran obyek 3D, kejelasan obyek media 3D, ketepatan pemilihan jenis teks, dan ketepatan ukuran teks. Kemudian 6 item dipilih dengan bobot nilai 3. Aspek yang tersaji dalam angket dengan perolehan bobot nilai 3 meliputi aspek kemenarikan media obyek 3D, kejelasan audio, kesesuaian audio, ketepatan Bahasa dalam penyampaian materi, keefektifan kata, kalimat, dan istilah, kemudahan memahami penjelasan materi melalui penggunaan Bahasa. Dari hasil analisis data ahli media diperoleh hasil $90 \%$. Berdasarkan kriteria telah ditetapkan dapat dijelaskan bahwa pengembangan 
obyek media 3D mata pelajaran Seni Budaya materi seni rupa 3D kelas X termasuk dalam kriteria valid atau layak untuk digunakan dalam proses pembelajaran.

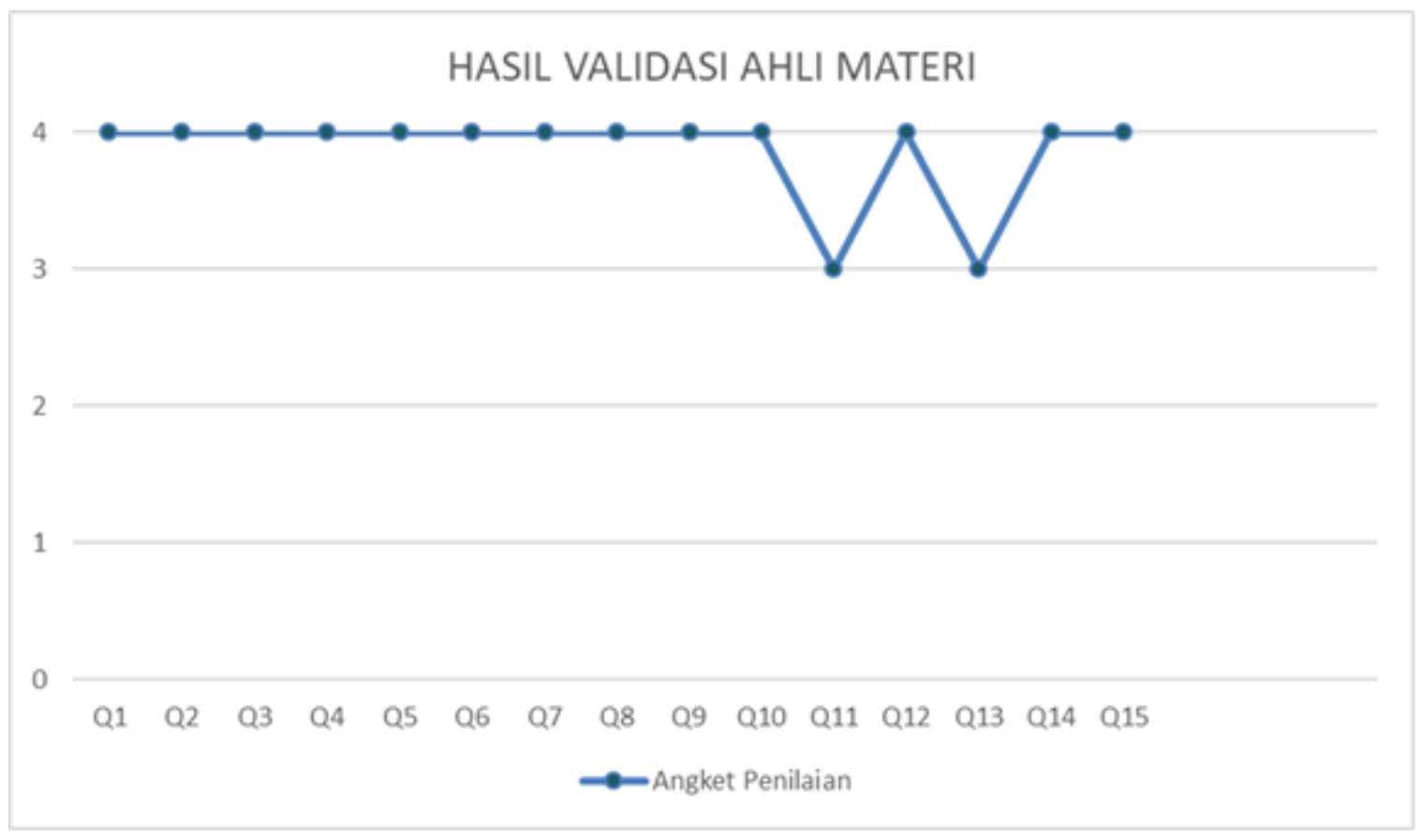

Grafik 2 Respon Ahli materi

Berdasarkan penyajian grafik 2 sebanyak 13 item menjawab dengan nilai 4. Aspek yang tersaji dalam angket dengan perolehan nilai 4 meliputi aspek kesesuaian materi dengan pembelajaran, kesesuaian keterangan dengan obyek 3D, kesesuaian bentuk obyek 3D dengan aslinya, kesesuaian contoh obyek 3D, kesesuaian judul media 3D dengan materi yang disampaikan, kesesuaian materi dengan buku pembelajaran, kesesuaian istilah-istilah, kesesuaian konsep dan definisi media obyek 3D, kesesuaian ilustrasi animasi media obyek 3D, kesesuaian konsep materi pembelajaran, kesesuaian materi dengan perkembangan ilmu pengetahuan, kesesuaian contoh obyek dalam kehidupan seharihari. Kemudian 2 item dipilih dengan nilai 3. Aspek tersaji dalam angket dengan nilai 3 meliputi aspek kesesuaian dalam kegiatan pembelajaran, dan keruntutan materi dalam penyampaian pembelajaran. Dari hasil analisis data ahli materi diperoleh hasil 96,6\%. Berdasarkan kriteria telah ditetapkan dapat dijelaskan bahwa pengembangan 3D pada mata pelajaran Seni Budaya 3D untuk kelas 10 termasuk dalam kriteria layak untuk digunakan dalam proses pembelajaran.

\section{PEMBAHASAN}

Media 3D Seni Budaya diproduksi dan dikembangkan berdasarkan tujuan pembelajaran. Menghasilkan produk dan memvalidasi media pembelajaran. Pengembangan 3D termasuk benda tiruan atau model. Pembentukan kembali objek nyata dengan skala yang berbeda. Model menurut Sihkabuden (2011:80) adalah benda tiruan berbentuk 3D menyerupai bentuk aslinya. Pemanfaatan model mengatasi masalah pembelajaran, seperti obyek berukuran besar atau luas yang sulit diamati keseluruhan.

Pendidikan vokasi atau kejuruan untuk meningkatkan pengetahuan, kepribadian, kecerdasan, dan keterampilan anak didik secara mandiri. Mengikuti pendidikan program keahlian untuk bekerja secara efektif, efisien, mengembangkan keahlian, dan keterampilannya. Pendidikan TKJ mampu beradaptasi dengan tuntutan teknologi. Pembelajaran media 3D dapat diterapkan di Kejuruan TKJ. Pengembangan media 3D sangat cocok untuk meningkatkan keterampilan anak didik dan menambah wawasan pengetahuan. Dengan media dapat meningkatkan minat dan motivasi belajar anak didik. 
Menurut Asyhar (2012), media merupakan obyek yang bentuknya dapat diamati secara keseluruhan dari berbagai arah dan memiliki panjang, lebar, dan tinggi. Siswa mengamati media 3D dengan melihat obyek sebenarnya secara detil. Siswa memanipulasi obyek media 3D dari segi bentuk dengan keterampilan yang dimiliki. Pemanfaatan media 3D tidak menghapuskan peranan buku ajar, tetapi media 3D untuk mencapai tujuan yang tidak dapat dicapai oleh perangkat pembelajaran di sekolah. Komponen media 3D yaitu: teks, gambar, audio, animasi, dan video untuk mengkonstruksi keterampilan memanipulasi siswa. Mengkonstruksi keterampilan memanipulasi adalah membangun keterampilan mengerjakan atau mengatur sesuatu dengan menggunakan keterampilan tangan (Nurwati, 2013).

Pengembangan 3D memiliki keunggulan diantaranya dari desain, kemenarikan objek 3D, kesesuaian objek media 3D dengan contoh dalam lingkungan sekitar, dan kejelasan bentuk objek media 3D. Beberapa kelebihan media 3D digunakan siswa untuk mengamati media 3D dengan melihat obyek sebenarnya secara detail.

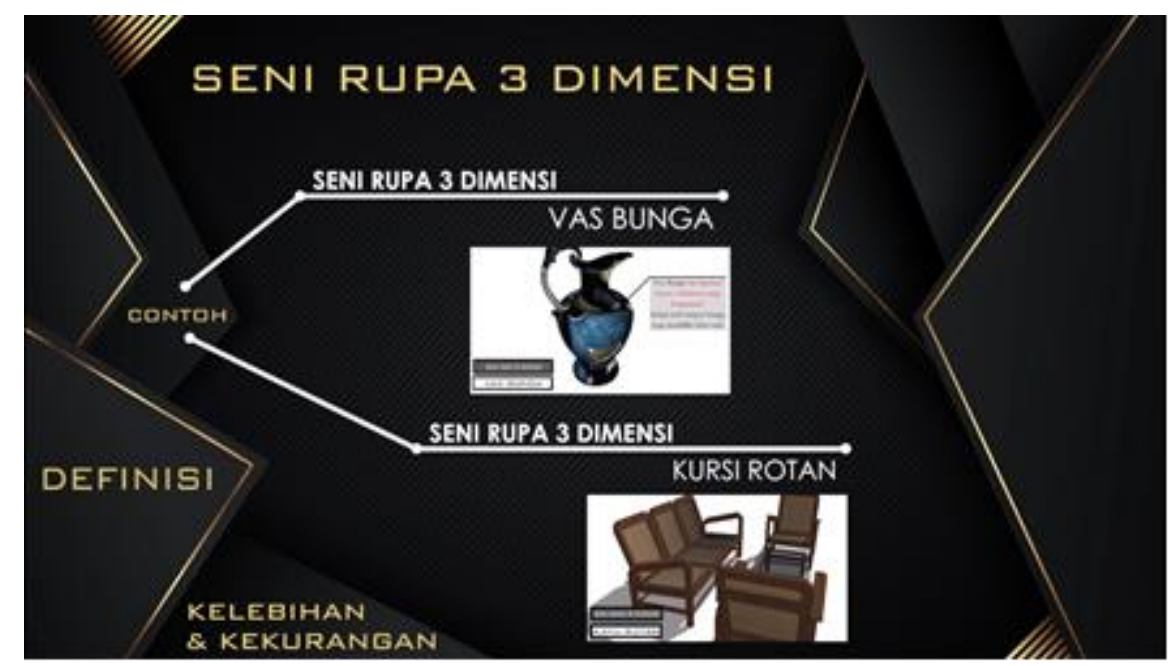

Gambar 2. Tampilan Produk Media 3D

Dalam produk pengembangan 3D meliputi file dengan format (.mp4) disimpan dalam CD (Compact Disk) dan flashdisk. Materi disampaikan dalam produk pengembangan 3D meliputi definisi seni rupa 3D, kelebihan dan kelemahan seni rupa 3D, dan contoh seni rupa 3D dalam kehidupn seharihari. Pemanfaatan media 3D menggunakan software grafis dan software editing video. Selanjutnya hasil rendering dari semua komponen dijadikan satu dengan format (.mp4) dan simpan dalam bentuk CD (Compact Disk) atau Flashdisk / media penyimpanan lainnya.

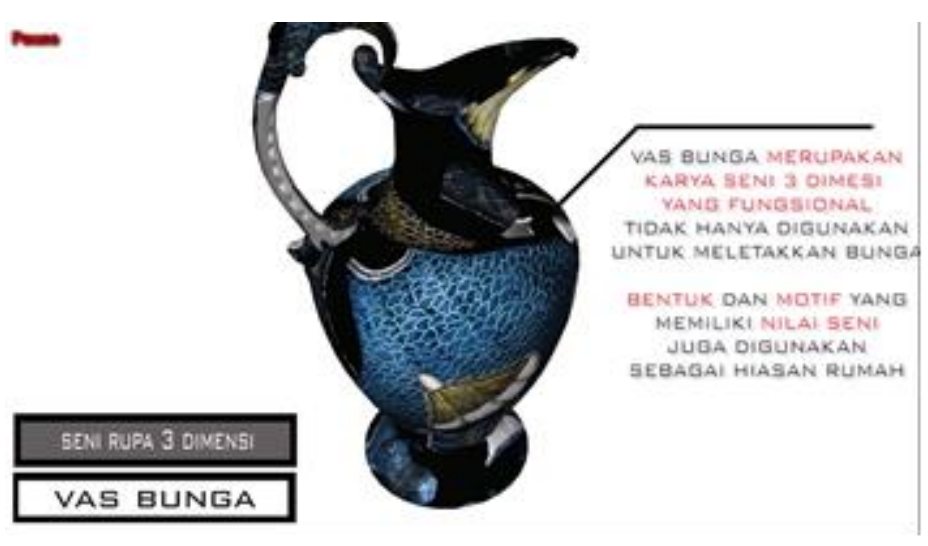

Gambar 3. Tampilan Obyek Media 3D 
Tahap pembuatan produk media 3D meliputi pembuatan modeling berupa perancangan obyek. Kemudian dilanjutkan editing dan pemberian animasi 3D, setelah semua objek selesai dibentuk maka objek-objek tersebut disatukan. Kemudian proses rendering untuk hasil keluaran dari adegan-adegan sebelumnya. Tahapan-tahapan ini cocok dengan Yuningsih (2018).

Pemanfaatan produk 3D menggunakan perangkat keras komputer atau handphone memiliki software pemutar video. Pemanfaatan 3D memasukkan file berformat (.mp4) kedalam perangkat untuk menjalankan pengembangan 3D. Produk pengembangan 3D dapat mempermudah pendidik dan anak didik dalam pembelajaran Seni Budaya. Manfaat pengembangan 3D untuk anak didik yaitu menarik minat belajar siswa. Bagi pendidik yaitu untuk membantu menyampaikan materi dengan semaksimal mungkin dan menambah variasi media.

Dalam pendidikan vokasi pengembangan 3D sebagai alat pembelajaran dengan memanfaatkan teknologi. Siswa TKJ memiliki kemampuan mengoperasikan komputer / laptop sehingga media objek 3D diamati secara langsung tanpa membawa contoh aslinya ke dalam kelas. Menampilkan visualisasi objek 3D siswa mengamati objek secara utuh. Sehingga anak didik memanipulasi obyek media dengan keterampilan yang dimiliki. Peserta didik meningkatkan kemampuan mengkonstruksi keterampilan memanipulasi obyek 3D yang diamati secara keseluruhan. Keterbatasan pada media 3D dalam pemanfaatanya membutuhkan alat seperti komputer /laptop untuk menjalankan media tersebut. Dan perlu pendamping guru seni budaya untuk menjalankan alur pembelajaran.

\section{SIMPULAN}

Hasil kelayakan pengembangan 3D dari ahhli media, materi, dan siswa. Pengembangan 3D dinyatakan layak digunakan dalam pembelajaran. Presentase menunjukkan dengan hasil perhitungan data statistik yaitu ahli media didapatkan skor presentase sebesar $90 \%$, ahli materi didapat skor presentase sebesar 96,6\%. Kelayakan media 3D digunakan dalam pembelajaran di sekolah. Namun ada kekurangan dalam media objek 3D, diantaranya memfokuskan media pembelajaran dan menambah contoh objek 3D pada materi seni rupa.

\section{DAFTAR RUJUKAN}

Ahmad, R. (1997). Media instruksional edukatif. PT Rineka Cipta

Arifudin, A., Kuswandi, D., \& Soepriyanto, Y. (2019). Pengembangan Media Obyek 3 Dimensi Digital Sel Hewan dan Tumbuhan Memanfaatkan Piramida Hologram Untuk MTS. Jurnal Kajian Teknologi Pendidikan, 2(1), 9-15

Arikunto, Suharsimi. (2006). Prosedur Penelitian Suatu Pendekatan Praktik Edisi Revisi VI. Jakarta: PT Rineka Cipta

Arikunto, Suharsimi. (2013). Prosedur Penelitian Suatu Pendekatan Praktik. Jakarta: PT Rineka Cipta

Arsyad, A. (2006). Media Pembelajaran. Jakarta: PT Grafindo

Asyhar, Rayandra. (2012). Kreatif Mengembangkan Media Pembelajaran. Jakarta: Referensi Jakarta

Atmoko, P. W. (2015). Digitalisasi dan Alih Media. Malang: Universitas Bramelati

Daryanto. 2014. Pendekatan Pembelajaran Saintifik Kurikulum 2013. Jakarta: Gava Media..

Kurniawan, D., Susilaningsih, S., \& Soepriyanto, Y. (2019). Pengembangan Media Obyek 3d Vacuum Circuit Breaker Memanfaatkan Piramida Hologram. Jurnal Kajian Teknologi Pendidikan, 2(1), 8-26.

Henderson, M., Selwyn, N., \& Aston, R. (2017). What works and why ? Student perception of 'useful' digital technology in university teaching and learning. Studies in Higher Education, 42(8), $1567-1579$.

Lanier, V. (1966). Newer Media And The Teaching Of Art. Art Education, 19(4), 5-8.

Latuheru, J. D. (1998). Media Pembelajaran Dalam Proses Belajar Mengajar. Jakarta: Departemen 
Pendidikan dan Kebudayaan

Lee, William W. \& Owens, Diana L. (2004). Multimedia-Based imstructional design. San Francisco: Pfeiffer.

Mardapi, Djemari. (2003). Penyusunan Tes Hasil Belajar. Yogyakarta: UNY

Munadi, Yudhi. 2013. Media Pembelajaran. Jakarata: Referensi.

Munadi, Yudhi. 2013. Media Pembelajaran : Sebuah Pendekatan Baru. Jakarta: Referensi.

Nuryanto, Imam R L, Suprijadi S, Siswanto A. (2018). Analisis Hasil Over Houl Pemutus Tenaga (PMT) 70KV. Conference on Innovation and Aplication of Science and Technology (CIASTECH 2018), 618-625. Retrivied from http://publishing-widyagama.ac.id/ejournalv2/index.php/ciastech/article/view/673/624

Nurwati, A. (2014). Penilaian Ranah Psikomotorik Siswa dalam Pelajaran Bahasa. Edukasia: Jurnal Penelitian Pendidikan Islam, 9(2), 386-400.

Hamalik, O. (2003). Media Pendidikan, Cetakan VI, Bandung: PT Citra Aditya Bakti.

Plowman, L. (2016), Learning Technology At Home and Preschool. The Wiley Handbook of learning Technology. Chichester, UK: WileyBlackwell, 96-112.

Read, H. (1959). The Meaning of Art atau Seni Arti dan Problematiknya. Terjemahan, Soedarso Sp.(2000).

Sadiman, Arief S. dkk, (2010). Media Pendidikan:: Pengertian Pengembangan dan Pemanfaatannya. Jakarta: Rajawali.

Seels, Barbara dan Richey, Rita C. Instructional Technology: The Definition and Domains of the Field. Bloomington: Association for Educational for Communiaction and Technology, 1994.

Sihkabuden. (2011). Media Pembelajaran. Malang: Departemen Pendidikan Nasional Universitas Negeri Malang Fakultas Ilmu Pendidikan

Smith-Zuzovsky, N., \& Exner, C. E. (2004). The effect of seated positioning quality on typical 6-and 7 -year-old children's object manipulation skills. American Journal of Occupational Therapy, 58(4), 380-388.

Sudjana, N. Ahmad Rivai. (2002). Media Pengajaran. Bandung: Alumni Bandung

Yaumi, M. (2018). Media dan Teknologi Pembelajaran. Prenada Media.

Yuningsih, F., Hadi, A., \& Huda, A. (2018). Rancang Bangun Animasi 3 Dimensi sebagai Media Pembelajaran pada Mata Pelajaran Menginstalasi PC. VoteTEKNIKA: Jurnal Vocational Teknik Elektronika dan Informatika, 2(2). 